\title{
KELEMBAGAAN LOKAL MINI PURSE SEINE DALAM PENANGKAPAN IKAN DI PERAIRAN SELAT BUTON KECAMATAN DURUKA KABUPATEN MUNA
}

\section{(LOCAL MINI PURSE SEINE INSTITUTION ON FISH CATCHING AT BUTON STRAIT WATER, DURUKA DISTRICT, MUNA REGENCY)}

\author{
La Boi ${ }^{1)}$, YaniTaufik ${ }^{2)}$, Laode $\mathrm{Geo}^{2)}$ \\ ${ }^{1)}$ Mahasiswa Program Studi Magister Agribisnis Universitas Halu Oleo \\ ${ }^{2)}$ Dosen Tetap Fakultas Pertanian Universitas Halu Oleo
}

Naskah diterima: 06 Juni 2018

Naskah direvisi: 17 Juni 2018

Disetujui diterbitkan: 29 Juni 2018

\begin{abstract}
The local institution of mini purse seine is a rule in the mini purse seine group that regulates the cooperation between skipper and labor in catching fish in the waters of Buton strait. In 2010, the number of mini purse seine in Lagasa Village was 40 units and continued to decrease to 30 units in 2017, the number of mini purse seine 30 units. This happens because the skippers sell their fishing gear to the other party as they do not have labors that do fishing. This study aimed to assess the capacity and role of local mini purse seine institutions in fishing in Buton strait waters, Duruka district, Muna Regency. The method of analysis used in this study is descriptive qualitative analysis with the skippers and labors of mini purse seine as the main informant. The results showed that the institutional capacity affecting the sustainability of mini purse seine fishing equipment is the presence of labor. The lack of labor in mini purse seine is caused by low catches, autocratic and symbolic leadership style of the skipper, and violation of the rule of catch fish. The institutional group of mini purse seine has a role in forming cooperative groups in fishing, establishing fishing business units, and advising Lagga Village Government in solving fishing problems in Buton strait waters. Recommendations: The government of Muna regency and its associated elements should increase the institutional capacity of mini purse seine through the strengthening of mini purse seine organizations, institutionalization of values or norms, and resource management.
\end{abstract}

Keywords: Mini Purse Seine, local institution, Bajo Tribe.

Intisari: Kelembagaan lokal mini purse seine merupakan aturan main dalam kelompok mini purse seine yang mengatur hubungan kerjasama juragan dan sawi dalam melakukan penangkapan ikan di perairan Selat Buton. Pada tahun 2010 jumlah mini purse seine di Desa Lagasa berjumlah 40 unit terus mengalami penurunan jumlah hingga pada tahun 2017 jumlah mini purse seine 30 unit. Hal tersebut terjadi karena juragan menjual alat tangkapnya kepada pihak lain akibat tidak memiliki tenaga kerja sawi untuk melakukan penangkapan ikan. Studi ini bertujuan untuk mengkaji kapasitas dan peranan kelembagaan lokal mini purse seine dalam penangkapan ikan di Perairan Selat Buton Kecamatan Duruka Kabupaten Muna. Metode analisis yang digunakan dalam studi ini adalah analisis deskriptif kualitatif dengan informan utama juragan dan sawi mini purse seine. Hasil studi menunjukkan bahwa kapasitas kelembagaan yang mempengaruhi keberlanjutan alat tangkap mini purse seine adalah keberadaan tenaga kerja sawi. Kurangnya tenaga kerja sawi pada mini purse seine disebabkan oleh hasil tangkapan ikan yang rendah, gaya kepemimpinan juragan yang otokratis dan simbolis, dan pelanggaran aturan main pembagian hasil tangkapan ikan. Kelembagaan kelompok mini purse seine berperan membentuk kelompok kerjasama dalam penangkapan ikan, membentuk unit usaha penangkapan ikan, dan memberikan saran kepada Pemerintah Desa Lagasa dalam penyelesaian masalah penangkapan ikan di Perairan Selat Buton. Rekomendasi: Pemerintah Kabupaten Muna dan unsur-unsur yang terkait harus melakukan peningkatan kapasitas kelembagaan mini purse seine melalui penguatan orgaisasi mini purse seine, pelembagaan nilai atau norma, dan pengelolaan sumberdaya.

Kata kunci: Mini Purse Seine, kelembagaan lokal, Suku Bajo. 


\section{PENDAHULUAN}

Aturan atau kebijakan yang ditetapkan pemerintah untuk melindungi dan memanfaatkan sumberdaya perikanan belum sepenuhnya mampu mengendalikan ekspoloitasi sumberdaya perikanan dan meningkatkan kesejahteraan nelayan kecil disebabkan lemahnya kapasitas lembaga pemerintah dan organisasi sosial politik, ketidakpatuhan terhadap peraturan perikanan, dan kegagalan kebijakan (Dang, et.all, 2017: 175-184). Selanjutnya Castro dan Lindstro (2010: 77-84) mengungkapkan bahwa sebagian besar upaya pengelolaan perikanan berfokus pada peraturan dan insentif ekonomi, sementara sangat sedikit yang memasukkan norma, dan bahkan kurangnya aspek kognitif kultural.

Lembaga sosiokultural lokal memainkan peran yang sangat kuat dalam menentukan tingkat kepatuhan dan kerja sama komunitas nelayan kecil dengan pemerintah. Institusi sosial budaya yang kuat menjamin kepatuhan dan kerjasama di antara para pemangku kepentingan (stakeholder) dan kebijakan nasional perikanan mampu bertindak agresif terhadap kepentingan para stakeholder. Pemanfaatan institusi lokal yang tumbuh dan berkembang dalam kehidupan masyarakat pedesaan telah membantu banyak rumahtangga miskin agar dapat bertahan hidup. Nilai-nilai lokal tersebut yang diterapkan dan dikembangkan nelayan mampu mengangkat derajat kehidupan nelayan di daerah pedesaan (Tirrell, 2017: 37-43)

Kelembagaan lokal perikanan perlu dikembangkan dan dipertahankan karena memiliki nilai-nilai budaya yang mampu menjaga kelestarian sumberdaya perikanan secara berkelanjutan (Alonso, et.all, 2016: 61-70). Namun disisi lain kelembagaan lokal masih memiliki peran yang terbatas karena kurangnya pembinaan, akses pasar dan permodalan, sehingga peranannya dalam pengentasan kemiskinan nelayan tidak optimal. Penerapan nilai-nilai budaya lokal pada komunitas nelayan tangkap belum dilaksanakan secara optimal sehingga menguntungkan pihak pemilik modal (Sipahelut, 2010: 87).

Colleta dan Michelle (2000: 14) menyatakan bahwa pengembangan kelembagaan tidak dapat dilepaskan dari kapital sosial yang ada. Kepercayaan, hubungan sosial dan norma merupakan tiga komponen penting yang mampu menjadi perekat elemen masyarakat. Apabila semuanya dapat berjalan dengan baik maka kapital sosial akan mampu menggerakkan sebuah lembaga yang efektif dan efisien dalam melaksanakan pembangunan.

Nelayan mini purse seine di Desa Lagasa Kecamatan Duruka Kabupaten Muna memiliki kepercayaan bahwa laut memiliki penguasa yang mengendalikan kehidupan di laut. Keyakinan ini menjadi dasar dari nelayan Bajo untuk menghargai segala sesuatu yang hidup di laut. Bentuk penghargaan terhadap laut tersebut dimanifestasikan dalam kehidupan mereka dalam menangkap ikan.Nelayan mini purse seine berpegang kepada nilai-nilai kepercayaan dalam mengambil keputusan dan membangun hubungan di internal anggota, masyarakat dan lingkungan laut. Perilaku yang tidak sesuai dengan nilai-nilai kepercayaan dalam membangun usaha diyakini akan berdampak buruk terhadap keberlanjutan usaha mini purse seine.

Keberlanjutan alat tangkap mini purse seine yang dioperasikan di Selat Buton dipengaruhi oleh keberadaan sawi sebagai tenaga kerja pada mini purse seine. Pada tahun 2010 jumlah mini purse seine di Desa Lagasa berjumlah 40 unit terus mengalami penurunan jumlah hingga pada tahun 2017 jumlah mini purse seine 30 unit. Hal tersebut terjadi karena juragan menjual alat tangkapnya kepada pihak lain akibat tidak memiliki tenaga kerja untuk melakukan penangkapan ikan. Mini purse seine yang tidak melakukan penangkapan ikan dalam jangka waktu yang lama akan membutuhkan biaya yang besar untuk melakukan perawatan kapal dan alat tangkap. Untuk menghindari kerugian yang lebih besar, maka para juragan menjual alat tangkapnya kepada pihak lain.

Kelembagaan lokal yang kuat akan menciptakan hubungan ekonomi dan sosial yang kuat diantara anggota kelompok nelayan dan mengembangkan tata kelola dalam usaha kelompok penangkap ikan yang menguntungkan dan berkelanjutan. Kepatuhan nelayan terhadap nilai-nilai budaya lokal dalam melakukan penangkapan ikan harus didukung oleh kapasitas kelembagaan sebagai suatu instrument yang akan memperkuat kedudukan nilai-nilai budaya tersebut dalam pemanfaatan sumberdaya ikan. 
Tujuan studi untuk mengkaji kapasitas dan peranan kelembagaan lokal mini purse seine dalam melakukan penangkapan ikan di perairan Selat Buton Kabupaten Muna.

\section{METODE STUDI}

Studi ini dilaksanakan pada tahun 2017, bertempat di Desa Lagasa Kecamatan Duruka Kapupaten Muna. Jenis studi ini adalah studi deskriptif, menggunakan pendekatan kualitatif. Informan utama adalah juragan dan sawi pada mini purse seine. Studi deskriptif dimaksudkan bahwa studi ini akan menggambarkan secara mendalam aspek-aspek fenomena sesuai fokus studi. Pendekatan yang digunakan dalam studi ini adalah kualitatif. Artinya, realitas sosial terkait aspek-aspek yang menjadi fokus studi didekati dari sisi kualitasnya berupa proses dari konstruksi realitas dan makna-makna dibalik realitas tersebut. Pengertian deskripsi secara kualitatif yaitu memberikan penjelasan tentang fenomena dengan mengumpulkan data dan dinyatakan dalam bentuk kata-kata dan gambar, kata-kata disusun dalam kalimat (Miles dan Huberman, 1992: 16).

\section{HASIL DAN PEMBAHASAN}

Kelompok mini purse seine adalah kumpulan nelayan yang ada di Desa Lagasa yang terbentuk atas dasar kesamaan kepentingan dan keakraban untuk meningkatkan dan mengembangkan usaha penangkapan ikan dengan menggunakan alat tangkap mini purse seine. Kelembagaan mini purse seine diartikan sebagai aturan main dalam kelompok mini purse seine yang mengatur peran juragan dan sawi dalam hubungan kerjasama melakukan penangkapan ikan di perairan Selat Buton. Norma atau aturan main dalam kelompok mini purse seine berasal dari nilai-nilai kepercayaan suku Bajo yang telah disepakati bersama yang berfungsi untuk memberikan pedoman berperilaku pada anggota mini purse seine dalam bertingkah laku atau bersikap dalam menghadapi berbagai permasalahan dalam internal kelompok terutama yang menyangkut kebutuhan-kebutuhan bagi anggota atau operasional penangkapan ikan, menjaga keutuhan kelompok mini purse seine untuk tetap menjaga kekompakan dan keharmonisan dalam melakukan penangkapan ikan, dan sebagai pegangan kepada anggota kelompok atau sistem pengawasan terhadap tingkah laku angota mini purse seine.

Kelompok mini purse seine yang terbentuk bertujuan untuk dapat melakukan penangkapan ikan melalui kerjasama anggota kelompoknya. Kerjasama juragan dan sawi yang terjaga akan menjadikan usaha penangkapan mini purse seine berkelanjutan. Permasalahan utama yang terjadi di Desa Lagasa adalah tidak terpenuhinya jumlah tenaga kerja sawi untuk melakukan penangkapan ikan. Bila ditinjau dari aspek kelembagaan, maka kurangnya tenaga sawi yang bekerja pada mini purse seine disebabkan oleh rendahnya hasil tangkapan ikan, kepemimpinan juragan yang otokratik dan simbolis, dan pelanggaran aturan main pembagian hasil tangkapan ikan. Kelembagaan kelompok mini purse seine berperan membentuk kelompok kerjasama dalam penangkapan ikan, membentuk unit usaha penangkapan ikan, dan memberikan saran kepada Pemerintah Desa Lagasa dalam penyelesaian masalah penangkapan ikan di Perairan Selat Buton.

\section{Kapasitas Kelembagaan}

Kelembagaan mini purse seien dapat dikaji dalam dua perspektif. Perspektif pertama, kelembagaan sebagai nilai, norma, aturan perilaku dan aturan main. Perspektif kedua, kelembagaan sebagai institusi/organisasi atau struktur. Ohama (2011) dalam Fausayana (2014: 13) mengungkapkan bahwa ada tiga unsur fundamental dalam sistem kemasyarakatan local yaitu: Resources (R), Organization $(\mathrm{O})$ dan Norm $(\mathrm{N})$.

a. Resources (R) (Sumberdaya)

Komponen-komponen sumberdaya dalam kelompok mini purse seine terdiri dari ketersediaan sumberdaya ikan, tenaga kerja, dan ketersediaan sarana penangkapan ikan (kapal dan alat tangkap mini 
purse seine) yang memiliki peranan penting dalam keberlanjutan kelompok mini purse seine. Kelompok mini purse seine di Desa Lagasa telah mengalami kekurangan tenaga kerja untuk melakukan penangkapan ikan. Hal tersebut salah satunya disebabakan oleh rendahnya hasil tangkapan ikan yang dilakukan selama satu bulan musim penangkapan ikan (1 doloma). Kapal mini purse seine yang memiliki hasil yang kurang dalam melakukan penangkapan ikan bagi kepercayaan sawi suku Bajo dianggap sebagai kapal yang sial dan tidak sesuai dengan sisi mereka untuk mencari nafkah.

Kepercayaan suku Bajo terhadap keberuntungan kapal dalam mencari ikan telah mempengaruhi keinginan seseorang untuk mengikuti kapal mini purse seine. Keberuntungan kapal mini purse seine ditentukan dengan jumlah hasil tangkapan yang diperoleh pada saat melakukan penangkapan ikan selama satu musim penangkapan. Mereka juga percaya bahwa seseorang memiliki kecocokan dengan kapal tertentu dalam melakukan penangkapan ikan yang ditunjukkan pula dengan jumlah hasil tangkapan saat mengikuti kapal tersebut. Apabila kapal yang diikuti memiliki hasil tangkapan yang tinggi maka dipercaya kapal tersebut memiliki kecocokan dengan dirinya.

Kapal mini purse seine di Desa Lagasa yang tidak cukup kebutuhan sawi untuk melakukan penangkapan ikan akan mengalami kerugian untuk menanggung biaya perawatan kapal dan alat tangkap. Untuk menghindari kerugian yang lebih besar maka juragan kapal mini purse seine akan menjual kapal miliknya kepada pihak lain. Dengan dijualnya kapal dan alat tangkap mini purse seine telah menunjukkan bahwa kelompok mini purse seine tersebut telah bubar dengan sendirinya sehingga tidak dapat melanjutkan aktivitas penangkapan ikan Dengan demikian, ketersediaan sumberdaya ikan akan mempengaruhi ketersediaan tenaga kerja sawi yaitu semakin besar hasil tangkapan ikan yang diperoleh akan semakin besar pula keinginan sawi untuk mengikuti kapal mini purse seine untuk melakukan penangkapan ikan, demikian pula sebaliknya bahwa semakin kecil hasil tangkapan ikan yang diperoleh dalam satu musim penangkapan maka semakin besar pula keinginan tenaga kerja sawi untuk tidak mengikuti kapal mini purse seine untuk melakukan penangkapan ikan.

\section{b. Organization $(O)$}

Kelompok penangkapan ikan dengan mini purse seine di Desa Lagasa termasuk dalam kelompok organisasi informal. Di dalam kelompok ini peraturan yang dijalankan tidak tertulis namun berdasarkan hasil kesepakatan yang diikuti secara turun- temurun.Struktur organisasi pada mini purse seine di dasarkan pada peran masing-masing personil mini purse seine.Terdapat dua kelompok anggota personil yang berperan sebagai pelaku pekerjaan yaitu juragan dan sawi. Besarnya peran masing-masing anggota dapat dilihat dari tingkat kesulitan dan tanggung jawab dari pekerjaan yang dilakukan. Peran antara juragan dan sawi pada mini purse seine tersebut secara tidak langsung telah membentuk uraian kerja dan hubungan interaksi masing-masing anggota.

Juragan sebagai pemilik mini purse seine berperan sebagai pemimpin atau ketua dalam pengoperasian mini purse seine. Juragan sebagai pemilik mini purse seine selalu mendapatkan rasa hormat dan penghargaan dari para sawi yang bekerja kepadanya. Kapasitas juragan dalam mini purse seine adalah sebagai pemimpin dan pemilik mini purse seine. Dengan kapasitasnya tersebut juragan memiliki peran sebagai berikut:

1. Menetapkan waktu dimulainya pelayaran untuk penangkapan ikan.

2. Menentukan fishing ground yang tepat.

3. Mengatur pembagian jame-jame (ikan bonus).

4. Melakukan pembagian hasil penjualan disetiap akhir musim penangkapan ikan (1 doloma).

5. Memberikan perlindungan maupun sanksi kepada sawi.

6. Menyediakan fasilitas utama dalam penangkapan yaitu kapal dan alat tangkap mini purse seine.

Sawi merupakan ABK (Anak Buah Kapal) atau tenaga kerja yang bekerja pada kapal mini purse seine. Posisi sawi dalam mini purse seine dibedakan menjadi dua bagian posisi utama yaitu sawi manajerial dan sawi operasional. Sawi manajerial ialah sawi yang diberi kepercayaan dan hak oleh juragan untuk memimpin dan memerintah sawi yang lainnya untuk mengerjakan pekerjaan sesuai perintah juragan. Posisi sawi manajerial hanya di duduki oleh satu orang, biasanya diberikan kepada 
kerabat dekat dari juragan (anak atau keponakan). Juragan sebagai pemilik kapal hanya mendapatkan laporan hasil tangkapan pada saat melaut ataupun masalah-masalah yang dialami saat melaut. Sawi manajerial ini dikenal juga sebagi juragan lapangan, dimana posisi dan kewenangannya dalam proses penangkapan ikan sama dengan juragan pemilik kapal, yaitu dapat memberikan perintah, teguran maupun nasehat kepada sawi operasional apabila melanggar aturan atau norma yang telah disepakati bersama. Sawi operasional ialah setiap orang yang secara langsung mengerjakan sendiri pekerjaannya sesuai dengan perintah juragan. Sawi operasional terdiri dari bas (juru mesin), padomba, penurun dan penarik jaring, dan penurun dan penarik cincin pemberat dan tali kolor. Kapasitas sawi adalah sebagai tenaga kerja yang mendapatkan hasil pembagian penangkapan ikan sesuai dengan kesepakatan bersama. Kedudukannya sebagai tenaga kerja, maka sawi berkewajiban untuk menjalankan dan mentaati semua intruksi dari juragan dalam kegiatan penangkapan ikan, dan menjaga nama baik dari kelompok. Peranan sawi dalam operasi penangkapan ikan adalah :

1. Membantu juragan melakukan kegiatan operasinal penangkapan ikan sesuai dengan keahlian masing-masing.

2. Membantu juragan dalam kegiatan perbaikan dan perawatan kapal dan alat tangkap.

3. Membantu juragan melakukan kegiatan manajerial untuk memimpin kegiatan penangkapan ikan.

Dalam organisasi kelompok mini purse seine di Desa Lagasa yang memegang peranan penting terhadap keberlanjutan kelompok mini purse seine adalah gaya kepemimpinan yang ditampilkan juragan terhadap tenaga kerja sawi dalam kelompok mini purse seine. Gaya kepemimpinan juragan diartikan sebagai pola tingkah laku (kata-kata dan tindakan-tindakan) dari seorang juragan yang dirasakan oleh para sawi sebagai bawahannya. Kepemimpinan juragan akan mempengaruhi keberadaan tenaga kerja sawi untuk tetap bekerja pada mini purse seine miliknya.

Gaya kepemimpinan juragan mini purse seine di Desa Lagasa yang menyebabkan tenaga kerja sawi keluar dari kelompok mini purse seine adalah sebagai berikut : (1) gaya kepemimpinan otokratik. Gaya kepemimpinan otokratik selalu memandang bahwa organisasi yang dipimpinnya merupakan milik pribadi, menganggap bawahan sebagai alat, tidak mau menerima kritik dan saran, dan tindakan pergerakannya sering mempergunakan pendekatan paksaan dan bersifat menghukum (Sugandi, 2011:140). Gaya kepemimpinan otokratik pada kelompok mini purse seine ditunjukkan dengan perilaku juragan yang kasar, tidak memperhatikan perasaan dan kebutuhan utama dari sawi. Posisi juragan saat itu adalah melakukan ekspoloitasi terhadap kebutuhan sawi. Contoh bentuk ekspoloitasi ini dapat terjadi pada saat dilakukan penangkapan ikan, dimana juragan tidak memberikan ikan jamejame kepada sawi setelah melakukan penangkapan ikan. Tujuan pemberian ikan jame-jame ini adalah untuk memenuhi kebutuhan hidup sawi sehari-hari sebelum mendapatkan hasil pembagian pendapatan diakhir musim penangkapan. Selain itu, juragan tidak memperhatikan perasaan sawi saat melakukan penangkapan ikan, dimana juragan melakukan instruksi kepada para sawi dengan bahasa yang tidak sopan atau tidak sesuai dengan adab tata krama. Perilaku tersebut menyebabkan para sawi akan keluar dari kelompok mini purse seine; dan (2) gaya kepemimpinan simbolik. Gaya kepemimpinan simbolik dicirikan dengan pendelegasian wewenang kepada orang lain. Gaya kepemimpinan simbolik pada kelompok mini purse seine ditunjukkan dengan pemberian kepercayaan dari juragan kepada sawi untuk memimpin operasi penangkapan ikan. Pendelegasian wewenang kepada sawi mengakibatkan kontrol juragan terhadap kondisi kelompok mini purse seine semakin berkurang. Kondisi tersebut seringkali dimanfaatkan oleh sawi untuk tidak melaporkan dengan jujur kepada juragan tentang jumlah hasil tangkapan ikan. Perilaku sawi ini menyebakan juragan mengalami kerugian. Untuk menghindari kerugian yang lebih besar, maka juragan menjual kapal dan alat tangkapmini purse seine miliknya. Ketidakjujuran sawi menjadi bentuk ekspoloitasi sawi terhadap juragan. Oleh karena itu, juragan selalu memberikan kepercayaan kepada orang-orang terdekatnya seperti anak ataupun keponakan dengan tujuan untuk menghindari tindakan yang tidak jujur saat diberi kepercayaan.

Gaya kepemimpinan juragan yang dapat mempertahankan tenaga kerja sawi adalah gaya kepemimpinan demokratik. Gaya kepemimpinan demokratik memiliki karakteristik dalam proses 
pergerakan bawahan selalu bertitik tolak dari pendapat bahwa manusia itu adalah mahluk yang termulia di dunia, selalu berusaha mensinkronisasikan kepentingan dan tujuan organisasi dalam kepentingan dan tujuan pribadi dari pada bawahannya, senang menerima saran, pendapat bahkan kritik dari bawahan, selalu berusaha menjadikan bawahannya sukses dan berusaha mengembangkan kapasitas diri pribadi sebagai pemimpin (Sugandi, 2011:141). Gaya kepemimpinan demokratik pada kelompok mini purse seine ditunjukkan dengan perilaku juragan yang menghargai dan menerima saran dari para sawi, serta memberikan perlindungan dan keadilan kepada para sawi. Juragan dapat memberikan solusi setiap permasalahan yang dihadapi oleh para sawi dengan bijaksana tanpa dengan menyakiti perasaan para sawi. Dengan gaya kepemimpinan juragan yang demokratis dapat memberikan kenyamanan kepada para sawi untuk bekerja dalam mini purse seine. Bentuk kepemimpinan juragan yang disenangi oleh sawi akan membuat sawi merasa terlindungi dan kebutuhan dasarnya dapat terpenuhi, sehingga membuat para sawi akan terus bekerja pada mini purse seine yang dipimpin oleh juragan yang bersangkutan. Demikian pula bagi juragan yang tidak memberikan kenyamanan akan ditinggalkan oleh para sawi.

\section{c. $\operatorname{Norm}(N)$}

Norma dalam kelompok penangkapan mini purse seine di Desa Lagasa dipandang sebagai tata aturan dalam kelompok mini purse seine yang dirumuskan oleh mereka sendiri untuk mengatur hubungan antar individu dalam kelompok tersebut. Norma dalam kelompok mini purse seine lahir dari komitmen bersama terhadap nilai sebagai pedoman dalam tingkah laku dan pengambilan keputusan yang dipengaruhi oleh nilainilai kepercayaan atau budaya masyarakat secara turun temurun.

Mini purse seine yang beroperasi di perairan Selat Buton berasal dari Desa Lagasa yang mayoritas merupakan etnis Bajo. Dasar mereka mengoperasikan mini purse seine dipengaruhi oleh kepercayaan yang mengatur hubungan antara sesama manusia dan hubungan dengan lingkungan laut. Sebagaimana yang dikemukakan oleh Suriamihardja (2012: 4) bahwa suku Bajo menganggap lautan sebagai (1) ruang kebersamaan untuk menjaga hubungan di antara sesama, dan bekerja sama dengan pihak lain untuk mencapai tujuan bersama; (2) ruang kekeluargaan untuk menjaga agar tidak saling mengganggu dan merugikan, sehingga mampu menerapkan strategi adaptif dalam mengatasi problematika yang dihadapi; (3) ruang persatuan untuk saling menolong, memberi dan menerima, dalam berbagai aktivitas di laut di antara sesama mereka. Dalam makna seperti ini, ruang bagi suku Bajo tetap berada pada kondisi pra-permukiman, yaitu kondisi perkelanaan, yang ternyata diperlukan sebagai bukti kedaulatan.

Suku Bajo di Desa La Gasa mempunyai pengetahuan budaya (culture knowledge) yang mencakup nilai-nilai, norma, dan kepercayaan yang melandasi perilaku dalam menguasai dan memanfaatkan sumberdaya perairan pesisir sebagai warisan leluhur yang diturunkan dari generasi ke generasi berikutnya.Sebelum memasuki awal penangkapan di musim gelap bulan, ada kepercayaan yang sudah dilakukan turun temurun yaitu mengadakan ritual doa keselamatan agar saat berlayar mendapatkan keselamatan dan mendapatkan limpahan rejeki. Ritual tersebut dipimpin oleh tokoh agama dalam kampung yang diselenggarakan dirumah juragan yang dihadiri oleh sawi yang akan ikut dalam satu musim penangkapan. Sawi yang ikut dalam ritual ini merupakan sawi tetap yang akan mendapatkan hasil pembagian hasil penangkapan diakhir musim penangkapan. Kehadiran seseorang dalam ritual ini sebagai tanda bahwa orang tersebut akan serius atau sungguh-sungguh mengikuti penangkapan ikan pada mini purse seine dalam satu musim penangkapan (1 doloma).

Suku Bajo yang ada di Desa Lagasa masih kuat memegang kepercayaan perihal keberadaan mahluk ghaib yang menguasai wilayah perairan laut. Kepercayaan ini yang menjadi dasar bagi nelayan mini purse seine untuk menjaga perilaku mereka pada saat melakukan pelayaran. Mereka harus dapat menjaga hubungan yang baik dengan lingkungan laut. Keyakinan ini yang menjadikan nelayan mini purse seine di Desa Lagasa memiliki kebiasaan-kebiasaan yang menjadi pantangan yang berkaitan dengan kegiatan melaut dan penangkapan ikan, antara lain: pantang berkata takabur (kotor ataupun sombong), patang membuang lombok dan jeruk nipis di laut, dan pantang mengambil air laut menggunakan belanga bekas memasak. Pantangan ini dilakukan untuk menghormati dan menghargai 
kehidupan yang ada di laut. Apabila pantangan ini dilanggar diyakini akan memberikan dampak buruk terhadap kegiatan penangkapan ikan.

Kelompok nelayan mini purse seine di Desa Lagasa telah menetapkan secara bersama besarnya hasil pembagian hasil penangkapan antara juragan dan sawi disetiap akhir musim penangkapan (1 doloma). Semua mini purse seine yang beroperasi tersebut memiliki aturan yang sama untuk pembagian hasil tangkapan. Aturan pembagian hasil yang diterapkan tidak tertulis secara formal akan tetapi kesepakatan ini terjadi secara lisan yang sudah berlangsung secara turun temurun. Adapun sistem bagi hasil yang berlaku adalah hasil penjualan ikan selama satu musim gelap akan dikurangi dengan biaya operasional (pembelian solar, pembelian suku cadang mesin dan biaya perbaikan). Hasil pengurangan tersebut (hasil bersih) selanjutnya dilakukan pembagian bagian juragan dan sawi yakni 1 bagian (50\%) adalah menjadi hak juragan (pemilik kapal) dan sisanya 1 bagian lagi (50\%) menjadi hak sawi. Bagian sawi kemudian dibagi lagi untuk sejumlah mereka yang terlibat dalam armada penangkapan.Pembagian untuk sawi tersebut dilakukan oleh juragan berdasarkan posisi dan tanggung jawabnya dalam armada penangkapan mini purse seine. Kurangnya tenaga kerja sawi yang bekerja pada mini purse seine disebabkan oleh pelanggaran terhadap norma atau aturan main yang telah disepakati bersama, terutama pelanggaran terhadap aturan main dalam pembagian hasil tangkapan, yaitu : (1) pencatatan hasil penangkapan ikan yang dilakukan oleh juragan tidak diperlihatkan kepada sawi; (2) Para sawi tidak diperkenankan untuk mengambil ikan jame-jame oleh juragan pada setiap dilakukan penangkapan ikan; dan (3) pembagian hasil tangkapan ikan tidak dilakukan dengan adil, dimana jumlah perolehan pembagian hasil bagi sawi yang rajin dan malas adalah sama jumlahnya.

Selain pembagian penghasilan dari akumulasi hasil penangkapan dalam satu musim penagkapan juga dilakukan pembagian hasil penangkapan pada setiap trip penangkapan saat proses penangkapan berlangsung. Pembagian ikan dalam proses ini disebut jame-jame (ikan bonus). Ikan jame-jame memiliki nilai sosial dan ekonomi dalam penangkapan ikan dengan mini purse seine. Jame-jame bagi sawi dapat membantu memenuhi kebutuhan hidup mereka sehari-hari sebelum pembagian hasil tangkapan diakhir musim penangkapan. Ikan jame-jame dapat dijual ataupun dapat dibawah pulang ke rumah. Apabila mendapatkan jame-jame dalam jumlah besar, maka ikan jame-jame itu sebagian dapat dijual dan sebagiannya lagi dapat dibawah pulang ke rumah dan dibagi kepada tetangganya. Jame-jame sudah menjadi tradisi yang memiliki nilai sosial yang akan membangun hubungan kebersamaan dan meningkatkan semangat dari para ABK untuk melakukan penangkapan ikan. Para ABK akan semangat untuk melakukan penangkapan agar mendapatkan jame-jame dalam jumlah banyak.

\section{Peranan Kelembagaan Lokal Mini Purse Seine}

Peran kelompok mini purse seine dapat diartikan sebagai segala sesuatu yang dilakukan oleh kelompokmini purse seine berdasarkan kedudukan dan fungsinya secara normatif di dalam masyarakat. Keberadaan kapal dan alat tangkap kelompok mini purse seine di Desa Lagasa sebagai bentuk perkembangan atau modernisasi alat tangkap ikan yang memiliki kemampuan melakukan penangkapan ikan dan tenaga kerja dalam jumlah lebih besar dibandingkan alat tangkap lain yang beroperasi di perairan Selat Buton seperti pancing dan pukat. Alat tangkap mini purse seine dioperasikan oleh beberapa orang membentuk suatu kelompok penangkap ikan yang saling bekerja sama dalam melakukan penangkapan ikan. Hubungan yang harmonis antar pekerja dalam kelompok mini purse seine menjadi kunci utama terjalinnya kerjasama dalam penangkapan ikan.

Kapasitas yang dimiliki kelompok mini purse seine sebagai unit alat tangkap ikan yang dioperasikan secara berkelompok telah memberikan peran penting kelompok mini purse seine dalam masyarakat dan pemanfaatan sumberdaya perikanan. Adapun peran kelembagaan kelompok mini purse seine dalam penangkapan ikan di perairan Selat Buton adalah sebagai berikut : (1) Membentuk kelompok kerjasama dalam penangkapan ikan. Kelompok mini purse seine dapat terbentuk dan terlaksana atas dasar hubungan kerjasama.Sumberdaya ikan tidak dapat dimanfaatkan dengan mini purse seine apabila tidak didukung oleh kemampuan sumberdaya tenaga kerja yang cukup dan mampu bekerjasama. Alat tangkap mini purse seine menangkap ikan dalam jumlah lebih besar dibandingkan 
alat tangkap lain sehingga membutuhkan jumlah keterlibatan tenaga kerja 12-15 orang untuk dapat melakukan penangkapan ikan. Kelompok yang terbentuk akan menjalin hubungan kerjasama dalam kelompok sesuai dengan tugas dan fungsinya masing-masing dalam operasional penangkapan ikan. Kerjasama kelompok mini purse seine tersebut telah membuka lapangan kerja bagi masyarakat Desa Lagasa dan sekitarnya yang bekerja sebagai nelayan; (2) Membentuk unit usaha penangkapan ikan. Kelompokmini purse seine telah membuka unit usaha dalam penangkapan ikan yang ada di Desa Lagasa. Hasil tangkapan ikan kelompok mini purse seine menjadi penyuplai kebutuhan ikan yang ada di Kota Raha. Unit usaha mini purse seine telah mampu memberikan penghidupan bagi stakeholder yang terlibat di dalamnya yaitu tenaga kerja (juragan dan sawi) dan bagi para pedagang pengumpul (papalele) yang ada di Pasar Laino. Mini purse seine memiliki ketergantungan terhadap keberadaan tenaga kerja sawi sehingga untuk mempertahankan usahanya seorang juragan harus mampu membangun hubungan yang baik dengan para sawi. Keberadaan unit usaha mini purse seine telah menciptakan hubungan social melalui ikatan patron klien antara juragan dan sawi yang memberikan keuntungan bagi kedua belah pihak terutama dalam pemenuhan kebutuhan mendasar dan mendesak. Keberadaan unit usaha ini menjadi social security dalam kehidupan masyarakat nelayan Desa Lagasa; dan (3) Memberi saran kepada Pemerintah Desa Lagasa untuk penyelesaian masalah penangkapan ikan. Kelompokmini purse seine memberi saran kepada pemerintah desa dalam menyelesaikan berbagai permasalahan penangkapan ikan yang ada di Perairan Selat Buton. Permasalahan yang sering terjadi dalam penangkapan ikan di peraiaran Selat Buton adalah terjadinya konflik dalam perebutan wilayah penangkapan ikan antara kelompok mini purse seine dan nelayan pancing. Wilayah konflik ini terjadi di wilayah penangkapan nelayan pancing daerah Kolese. Untuk menyelesaikan permasalahan tersebut kelompok mini purse seine memberikan saran kepada Pemerintah Desa Lagasa untuk mengadakan pertemuan dengan nelayan pancing yang ada di daerah Kolese dan unsur-unsur yang terkait. Walaupun permasalahan konflik ini belum terselesaikan sampai sekarang, namun usaha yang dilakukan oleh kelompok mini purse seine untuk menyelesaikan konflik ini telah mereka lakukan melalui pelibatan Pemerintah Desa Lagasa.

\section{KESIMPULAN DAN REKOMENDASI}

Hasil studi menunjukkan bahwa kapasitas kelembagaan yang mempengaruhi keberlanjutan alat tangkap mini purse seine adalah keberadaan tenaga kerja sawi. Kurangnya tenaga kerja sawi pada mini purse seine disebabkan oleh hasil tangkapan ikan yang rendah, gaya kepemimpinan juragan yang otokratis dan simbolis, dan pelanggaran aturan main pembagian hasil tangkapan ikan. Kelembagaan kelompok mini purse seine berperan membentuk kelompok kerjasama dalam penangkapan ikan, membentuk unit usaha penangkapan ikan, dan memberikan saran kepada Pemerintah Desa Lagasa dalam penyelesaian masalah penangkapan ikan di Perairan Selat Buton. Rekomendasi: Pemerintah Kabupaten Muna dan unsur-unsur yang terkait harus melakukan peningkatan kapasitas kelembagaan mini purse seine melalui penguatan orgaisasi mini purse seine, pelembagaan nilai atau norma, dan pengelolaan sumberdaya.

\section{DAFTAR PUSTAKA}

Alonso, E.B., Houssa, R and Verpoorten, M. 2016. Voodoo Versus Fshing Committees: The Role of Traditional and Contemporary Institutions in Fsheries Management. Ecological Economics. Vol. 122: 61-70.

Castro, M.T and Lindstrom, L. 2010. Fishing Institutions: Addressing Regulative, Normative and Cultural-cognitive Elements to Enhance Fsheries Management. Marine Policy. Vol. 34: 77-84. 
Colleta, Nat J dan Michelle L.C. 2000. Violent Conflict and The Transformation of Social Capital. Washinton DC. World Bank. p 14.

Dang, N.B. Momtaz, S. Zimmerman, K. and Nhung, P.T.H. 2017. Effectiveness of Formal institutions in Managing Marine Fsheries for Sustainable Fisheries Development: A Case Study of a Coastal Commune in Vietnam. Ocean \& Coastal Management. Vol. 137: 175-184.

Fausayana, I. 2014. Budaya Teknologi dan Lending Model Usaha Rumput Laut Pada Kelembagaan Lokal di Kecamatan Konawe Selatan Provinsi Sulawesi Tenggara. Disertasi: Universitas Hasanuddin. Makassar. hlm 13.

Miles, B.B. dan Huberman, AM. 1992. Analisa Data Kualitatif. UI Press Jakarta. hlm 16.

Sipahelut, M. 2010. Analisis Pemberdayaan Masyarakat Nelayan di Kecamatan Tobelo Kabupaten Halmahera Utara. Tesis. Departemen Pemanfaatan Sumberdaya Perikanan. Sekolah Pascasarjana Institut Pertanian Bogor. hlm 87.

Sugandi, S. 2011. Administrasi Publik. Edisi pertama, cetakan pertama. Graha Ilmu. Yogyakarta. hlm $140,141$.

Suriamihardja. 2012. Keterkaitan Ekologi antara Pengembangan Permukiman Atas Air (PPA) dengan Upaya Konservasi Pesisir. Makassar. LP2M UNHAS. hlm 4.

Tirrell, A. 2017. Sociocultural Institutions in Norwegian Fisheries Management. Marine Policy. Vol. 77: $37-43$. 